\title{
THE EUROPEAN UNION AND MINORITIES
}

\author{
Ana Irina IRIMIA \\ IRIMIA_ANA_IRINA@YAHOO.COM \\ “AL.I. CUZA" POLICE ACADEMY, BUCHAREST, ROMANIA
}

\begin{abstract}
We are currently in the process of making a Europe where the elements of national sovereignty will be narrowed through the sharing of sovereignty and for collective security. Another trend in the field was that of regionalization of the importance and implications of this issue, explicitly or implicitly considered as belonging to Central and Eastern Europe. Such an assessment neglects the significance of a number of factors pertaining to the historical and political developments has on the matter, particularly regarding economic development of Central and Eastern Europe areas, and that the conflictual degeneration of perceiving ethnical, cultural and regional otherness is not a phenomenon which affects this space alone, but also the West. In contradiction with this point of view, some foreign experts in the field say it is a social reality that discrimination and intolerance connected to religion and ethnicity can be found in all meetings of the world and in countries with different economic development phases.
\end{abstract}

\section{Keywords}

European Union, minorities, state, rights, discrimination

\section{Introduction}

Originally, the 1956 Treaty of Rome establishing the European Economic Community and even the subsequent amendments did not contain provisions regarding the rights of national minorities.

Nevertheless, within the European Union, appreciating European linguistic and cultural diversity, on the $16^{\text {th }}$ of October, 1981 the European Parliament adopted a resolution to a Common Charter for Regional Languages and Cultures and Ethnic Minority Rights. The document was intended to encourage governments to improve legislation aimed at this problem. The European Parliament Commission adopted in 1989 a project of a Charter for national minorities' rights [1].

Also, previously, in 1977, the Community Council adopted a directive on the education of migrant workers' children, according to which Member States are required to take appropriate measures to facilitate the integration of migrants' children from countries of the Community, by teaching the official language of the host country and by promoting the teaching of these children's mother tongue and culture of origin. Subsequent assessments show that the Member States are far from implementing those provisions.

Various proposals and resolutions on various topics relating to ethnic minority 
groups were submitted in the European Parliament. Jeak H.A. Vandemenlebrache, Belgian MP, proposed a draft resolution (83-0690/90) for a European right of national minorities.

A special significance is assigned to the report made by the Count of Stanffenberg, elaborated by the empowerment of the Legal and Citizens' Rights Commission that define the notion of ethnic group by highlighting four elements:

1. the presence in a Member State shall be for generations;

2. they distinguish from a linguistic, historical, and/or religious point of view from the general population;

3. they have a specific cultural identity;

4. they constitute a demographic minority in that state.

The European Union, although it was not in principle obliged to deal with issues concerning the rights of persons belonging to minorities, which are of the state's national competence, except only the cases concerning labour movement and its terms, given this concern for peace and stability of the European continent, the institution in question plays a role that cannot be neglected in building interethnic cooperation and understanding relations in those member states.

In this sense one can interpret the provision of the Treaty of Maastricht from the $7^{\text {th }}$ of February, 1992 which requires the Community to "contribute to the building of the Member States' culture, while respecting their national and regional diversity and highlighting the common cultural heritage" [2]. It is thus recognised the necessity to protect regional, linguistic and cultural diversity. The European Community's initiative on convening a peace conference in Hague and the creation of an arbitration committee, named after the President or "Bandinter" Committee, can be included in the involvement of the European Union in the matter of minorities. This Committee issued a declaration stating the conditions to be fulfilled in the recognition perspective by the new states in Eastern Europe and the former Soviet Union.
Here, among others, it is provided the obligation of the new states to respect human rights and to guarantee the rights of ethnic and national groups and minorities, in accordance with the commitments undertaken within C.S.C.E. (the Organization of security and cooperation in Europe December) [3]. Consequently, it appears that the statement does not establish new rules about minorities, but it refers to C.S.C.E. commitments. Please note, however, that recognition is a public act of any sovereign state that is not subject to prescribed conditions regarding the policy of the recognized state. In a 1949 report of the Committe for Legal and Administrative Affairs within the Parliament Assembly, it was recognised the importance of the issue for greater protection of the rights of national minorities.

However, the European Convention on Human Rights [4] subsequently adopted by the European Council includes general provisions on the rights of persons belonging to minorities, limiting to provide in art. 14 that "the exercise of the rights and freedoms set forth in this Convention shall be secured without discrimination, based in particular on sex, race, colour, language, religion, political or other opinions, national or social origin, association with a national minority, property, birth or other status".

This text is clearly a case of nondiscrimination clause concerning, among other reasons, the affiliation with a national minority. The provisions of this article cannot be invoked unless one of the rights mentioned in the foregoing Articles of the document is breached (the right to life, personal freedom and safety, fair trial, private life, etc.) and therefore does not constitute an independent regulation of minority rights [5]. In implementing art.14 of the Convention, the European Court of Human Rights has developed an interesting jurisprudence that surpassed the limited nature of that provision.

The European evolution of minority rights was generated in greater extent by the relations between the Central European and Eastern European states, as well as those 
between them and those in Western Europe. Also, boosting an effective minorities' problem resolution process on the continent was determined by the idea of building a multicultural Europe, a thesis which was manifested starting with the 1960s [6]. Last but not least, we notice a growing interest for minorities within the context of the fall of the Berlin Wall and the bloody disintegration of Yugoslavia and the USSR.

The result of these trends and developments in the field of minority issues - has resulted in the adoption within the European Community of two conventions that are directly linked to the protection system of persons belonging to minorities, namely the European Charter for Regional and Minority Languages and the Framework Convention for minority protection, documents that we will present further.

\section{The European Charter for Regional and Minority Languages}

The purpose of this document is to promote the use of regional and minority languages as "an expression of cultural wealth" and to contribute to a Europe based on the principles of democracy and cultural diversity within the national sovereignty and territorial integrity.

The Charter defines the term "regional and minority languages" as languages traditionally used within a given territory of a state by its citizens who form a group numerically lower than the general population and that differs from the official language of the state, without including dialects and languages migrations (art. 1).

The Charter is structured into five parts (general provisions, objectives and principles, measures to promote the use of regional and minority languages in public life, implementation and final provisions), present, in order to promote the goals of this document, the characteristics of establishing a "set" of measures from which Member States can choose what will be implemented internally [7].

In addition to this flexibility, the Charter stipulates in art. 19 para. 1 a number of only 5 ratifications to enter into force. The intention of the authorities to write that document in such a way as to produce effects in the shortest time is obvious. The merit of the authors of this document is that, in a time when the trend in favour of resuscitating European minority protection was not yet quite clear, managed to provide the status of certain minority rights in an international convention. On the other hand, the possibility to choose granted to the states may lead to adopting superficial or vaguely defined measures from the set of measures provided by Part III of the Charter, namely adequate measures to protect the language, in education (art. 8), justice (art. 9), administration and public services (art. 10), means of communication (art. 11), cultural (art. 12), economic and social life (art. 13).

Note only that, for culture, the Charter emphasizes the importance of employment persons that have very good knowledge of regional or minority traditions, facilitating direct participation of minority groups in planning cultural activities, elaborating anf promoting economic, administrative, commercial, ethnic, legal, etc. language, appropriate in minority languages.

This generous situation meets a real need for flexibility, resulting from the different situation of the Council's Member States, of regional and minority languages spoken and the minorities living in their territories. The positive side of the document is its practical definition. Hence, the parties must periodically submit a report on the measures taken in the given field, and a "Committee of independent experts", instituted as an effect of the Charter, will examine these reports.

\section{The framework Convention of} minority protection

It was adopted on the $10^{\text {th }}$ of November, 1994 and open for signing on the $1^{\text {st }}$ of February, 1995. Romania signed the Framework Convention on $1^{\text {st }}$ of February, 1995 in Paris, and in the same year it ratified the document [8]. The Framework Convention was adopted instead of an additional 
protocol to the European Convention of Human Rights, proposed by Recommendation 1201 of the European Council.

The Framework Convention is the first multilateral treaty exclusively regulating minority protection. For this reason, the provisions of this document were formulated with greater rigor and caution. Within the context, states have imposed rather pragmatic purposes of their policy without actually stipulating any right which minorities may avail as such (directly) [9].

Also, the Framework Convention, as other international documents, does not contain a definition of the notion of "national minority" and it does not recognize in any way the existence of collective rights in the case of persons belonging to minorities.

There are also situations where the terms used, such as "where possible", "within the national legal systems", "if there is sufficient demand" etc., highlight the flexibility of the provisions in the Convention concerning the solutions relating to the peculiarities of the Member States.

Title I of the Framework Convention (art. 1-3) contains general provisions enshrining the protection of national minorities and the rights of persons belonging to them as part of the international protection of human rights (art. 1), the implementation of the Convention in good faith in the spirit of understanding, tolerance and respect for good neighborliness, friendly relations and cooperation between states (art. 2), the right of minorities to freely choose whether or not to be treated as such without any disadvantage to arise from the law (art. 3, para. 1), as well as the capacity of these persons to exert the rights provided in the Framework Convention, individually or jointly with others (art.3, para. 2).

The first two articles reiterate norms known for a long time in international public law. In what concerns art. 3, it brings an element of novelty [10].

Title II (art. 4-19) contains provisions which stipulate a set of specific principles: equality and prohibition of discrimination (art. 4), right to own's culture and identity (art. 5), the obligation to encourage a spirit of tolerance (art. 6), freedom of assembly, freedom of thought, conscience, religion (art. 7), the right to manifest one's religion and to establish religious associations (art. 8), freedom of expression (art. 9), the right to use one's own language in private and in public, orally and written (art. 10), the right to use one's name and surname in the minority language (art. 11), the obligation to adopt measures in the field of education in order to encourage the knowledge of culture, history, language and religion, both that of the minorities, as well as those of the majority (art. 12), the right to establish and administer private educational institutions (art. 13), the right to learn one's minority language (art. 14), the right to participate in the cultural-social and economic life, as well as in public affairs (art. 15), refraining from measures which, altering the proportions of the population in areas inhabited by persons belonging to national minorities, are against the rights and freedoms resulting from the principles written in the Framework Convention (art. 16), states refraining from violating the rights of minorities to establish and maintain contacts across frontiers (art. 17), the parties will endeavor to conclude bilateral and multilateral agreements with other countries, especially with neighbouring countries for the protection of minorities (art. 18), taking it upon themselves to comply with the principles of the Convention, adopting only those amendments or limitations, restrictions and derogations provided in the international legal instruments, especially in the Convention for the Protection of Human Rights and Fundamental Freedoms $(C E D O-E C H R)$ to the extent in which they are relevant to the rights and freedoms resulting from the mentioned principles (art. 19).

Some of the provisions of the Framework Convention (those relating to equality, nondiscrimination, religious freedom, religious cult) do nothing but reinterpret in a slightly modified form, the provisions from universal or regional international documents, meant to protect human rights. Novelty items are 
recorded on the right to use the name in one's own language or concerning rights to cross-border contacts with people of the same language, ethnicity or religion. It is worth mentioning that the provisions of art. 18 regarding the limitations made in implementing the principles of the Framework Convention are rather vague and will not raise questions of interpretation.

Title III (art. 20-23) contains provisions regarding the implementation and interpretation of the Convention. Therefore, art. 20 stipulates the obligation of persons belonging to a national minority to comply with national laws and the rights of the majority or other minorities, art. 21 prohibits to interpret the Convention in a manner that would involve a breach of sovereign equality, territorial integrity or political independence of the states, and art. 22 prohibits interpretations that might affect human rights and fundamental freedoms. Art. 23 stipulates a priority of the Convention for the Protection of Human Rights and Fundamental Freedoms in interpreting the Framework Convention provisions on the same subject.

The fourth title (art. 24-26) deals with the supervision and control on the way the Convention is implemented by the parties, setting, in this respect, tasks to the Committee of Ministers of the Council of Europe (art. 24) the General Secretariat of the Council of Europe (art. 25) providing for the establishment of an Advisory Committee to assist the Committee of Ministers in order to evaluate the system for protecting national minorities (art. 26).

Title $\mathrm{V}$ contains the final provisions based on model clauses for conventions and agreements concluded within the Council of Europe. The Convention is open to those countries that are not members of the Council of Europe.

\section{Conclusions}

Intolerance is fanatized by dictators and by so-called democrats in order to acoomplish their own petty interests and policies. One of the known general obligations of persons belonging to minorities, which in a way can be considered a specific obligation, is the loyalty or fidelity to the country they live in.

Problems arising in connection with the exercise of specific rights of persons belonging to minorities, certify that the treatment of such persons is, ultimately, a matter of political and constitutional organization of the states, hence it is a part of the state's "domestic business", such as other matters of civil, criminal, administrative legislation and jurisdiction, many of them being directly connected to the rights of these people and therefore to the protection of their identity.

\section{Aknowledgement}

This paper had financial support through the project entitled ${ }^{\mathrm{PhD}} \mathrm{Phd}$ and-PhD Studies Orizont 2020: promoting national interest through excellence, competitiveness, and responsibility in the fundamental and applied Romanian scientific research'; contract identification number: POSDRU/1591.5/S/140106. The project is co-financed from the European Social Fund through the Sectoral Operational Programme Human Resources Development 2007-2013. Invest in People!

\section{References}

1. Thornberry Patrick, International Law and the Rights of Minorities, (Oxford: Calerendon Press, 1993) 299.

2. De Witte, B., The European Community and its Minorities (in Peoples and Minorities in Internațional Law) 167 și urm. apud. Diaconu Ion, Minoritățile și autodeterminarea popoarelor, (in "Drepturile Omului" magazine, nr. 2, 1996) 43

3. Charpentier, J., Les declarations des Douze sur la reconnaissance des nouveaux Etats, (in Revue Generale de Droit International Public, no. 96, 1962) 343-355 
4. Adopted in Rome on the $4^{\text {th }}$ of November, 1950. It entered into force on the $3^{\text {rd }}$ of September, 1953. Romania ratified the Convention and its additional protocols by Law no. 30 from the $18^{\text {th }}$ of May, 1994, "Official Gazette" no. 135/1994. Protocol 11 was ratified in July 1995 by Law no. 179

5. Donna Gomieu, Introducere în Convenţia Europeană a drepturilor Omului, (Bucharest: All Publishing House, 1993), 127.

6. The Lannung Report, Naţiunile Unite, Doc. 1299, 26 April 1961. With Scandinavian origin and effective American practice, the multicultural society concept is explained by the economic interests of the states.

7. Article 2 para. 2 requires that states undertake to apply a minimum of 35 paragraphs stipulating, however, that at least three must be selected from Articles 8 (on education) and 12 (Cultural activities and facilities) and one from Articles 9 (justice), 10 (administrative authorities and public services), 11 (communication media) and 13 (economic and social life). A wide variety of choices so is, on the one hand, positive because it reflects the European language mosaic, and on the other negative side, it is left too much to the political will of governments.

8. Romania ratified the Framework Convention by Law no. 33 from the $29^{\text {th }}$ of April, 1995, published in the "Official Gazette", Part I, no. 82 from the $4^{\text {th }}$ of May, 1995.

9. R. Hofman, "Die Rolle des Europarates beim Minderheitenschutz", in Mohr Manfred, Friedenssichernde Aspekte des Minderheitenschutz in der Arc des Volkerbundes und des Vereinten Nationen in Europa, (Berlin, Heidelberg Springer Verlag, 1996) 131.

10. The minorities' right of choice is also consecrated in the U.N. Declaration of 1992, but it does not have the effect of creating obligations for states.

\section{Bibliography}

Capotorti, Francesco. in Study on the Rights of Persons besoning to Ethnic, Religios and Lingvistic Minorites, (United Nations, New York, 1991).

Charpentier, J. "Les declarations des Douze sur la reconnaissance des nouveaux Etats". In Revue Generale de Droit International Public, 96, (1962).

Diaconu, Ion, "Minorităţile şi autodeterminarea popoarelor". In revista Drepturile Omului, 2 (1996).

Eckart, Klein. Die Frage der Minderheiten definition, în Mohr, Manfred Friedenssichernde Aspecte des Minderheitenschutzes în (der Ara der Völkerbundes und der vereinten Nationen in Europa, Springer Verl., Berlin, Heidelberg, 1996).

Gomieu, Donna. Introducere în Convenţia Europeană a drepturilor Omului. Bucharest: All Publishing House, 1993.

Hofman R. Die Rolle des Europarates beim Minderheitenschutz, în Mohr Manfred, Friedenssichernde Aspekte des Minderheitenschutz in (der Arc des Volkerbundes und des Vereinten Nationen in Europa, Springer Verlag, Berlin, Heidelberg, 1996).

Jellinek, G. "Das Recht der Minoritäten”. In Zeitschrift für Privat-und öffentliches Recht der Gegenwart, (1989).

Johabbessen, Lene, and Nyenegard. Lassen, Chirsten, Minority Ridhts in Europe - Progress in the C.S.C.E. The Danish Center for Human Rights, 1992.

Joust, Herman. "Protecţia Internaţională a drepturilor minorităţilor". In Liga Naţiunilor in R.R.D.O., 12 (1996).

Thornberry, Patrick. International Law and the Rights of Minorities. Oxford: Calerendon Press, 1993. 
Wolfrum, R. "New Minorities" as a Result of Migration, in peoples and Minorities in International Law", edited by Catherine Brosmann, Reme Lefeber, Marjoleine Zieck, Martinus Nijhoff Publishers, Dordrecht/Boston/London, 1993.

Yadh, Ben, Achaur. "Souverainite etatique et protection internationale des minorities". In Rd.C, vol 245, 1994. 